\title{
IN VITRO EFFECTS OF CEFTRIAXONE ON GROWTH OF HUMAN RHABDOMYOSARCOMA (RD) AND ON RAT EMBRYO FIBROBLASTS (REF) CELL LINES
}

\author{
Nada N. Al-Shawi* \\ Assistant Professor, Department of Pharmacology and Toxicology, College of Pharmacy, University of Baghdad, \\ Baghdad- Iraq
}

Received on: 22/10/12 Revised on: 30/11/12 Accepted on: 15/12/12

\author{
*Corresponding author \\ E-mail: nadaalshawi@yahoo.com \\ DOI: $10.7897 / 2277-4343.04121$ \\ Published by Moksha Publishing House. Website www.mokshaph.com \\ All rights reserved.
}

\section{ABSTRACT}

Many reports demonstrated that antibiotics like cefazoline, ciprofloxacin, trimethoprime-sulfamethoxazole and others have the ability to inhibit growth of various cell lines. Thus, this study was designed to investigate whether or not ceftriaxone may possess cell growth inhibition using In vitro study and utilizing two cell lines (human rhabdomyosarcoma (RD) and rat embryo fibroblasts (REF). Various concentrations of Ceftriaxone (62.5, $125,250,500$ and $1000 \mathrm{mcg} / \mathrm{ml}$ ) were utilized in this study. The drug relatively caused concentration-dependent inhibition on growth of the intended cell lines used in this study, where, the growth inhibition induced by the drug was statistically significant at $125 \mathrm{mcg} / \mathrm{ml}$ and above. The results obtained from this work encourage further study of the possibility of clinical application of ceftriaxone to prevent the occurrence of different tumors. Keywords: In vitro study, ceftriaxone, RD cell lines, REF cell lines, Growth inhibition

\section{INTRODUCTION}

Ceftriaxone, a bactericidal $3^{\text {rd }}$ generation cephalosporin, belongs to $\beta$-lactam group of antibiotics. It has broad spectrum activity where it acts by inhibiting bacterial cell wall of many Gram-positive and Gram negative bacteria ${ }^{1}$. Rhabdomyosarcoma (RD), a cancer of connective tissues, in which the cancer cells are thought to arise from skeletal muscle progenitors. Mostly occur in areas naturally lacking in skeletal muscle, such as the head, neck, and genitourinary tract $^{2}$. Rat embryo fibroblast cell line (REF) was considered the most important source for the undifferentiated fibroblastic culture ${ }^{3}$. Many reports demonstrated that antibiotics like cefazoline, ciprofloxacin, trimethoprime-sulfamethoxazole and others have the ability to inhibit growth of various cell lines ${ }^{4,5}$. Thus, this study was designed to investigate whether or not ceftriaxone may possess cell growth inhibition using in vitro study and utilizing two cell lines, human rhabdomyosarcoma (RD) and transitional rat embryo fibroblasts (REF).

\section{MATERIALS AND METHODS \\ Chemicals}

Ceftriaxone vial $1193 \mathrm{mg}$ ceftriaxone disodium salt (equivalent to $1000 \mathrm{mg}$ ceftriaxone base as dry powder for injection, was freshly reconstituted in $10 \mathrm{ml}$ distilled water and used in the present study as stock solution), and it was utilized to prepare different concentration (1000, $500,250,125$ and $62.5 \mathrm{mcg} / \mathrm{ml}$ ) of the drug. Other chemicals were of analytical grade.

\section{Cell lines}

Both human rhabdomyosarcoma and the transformed rat embryo fibroblast cell line were obtained from Iraqi Center for Cancer and Medical Genetic Researches (ICCMGR). They were maintained in RPMI-1640 medium supplemented with $10 \%$ heat-inactivated fetal calf serum, benzyl penicillin solution, streptomycin, nystatin and sodium bicarbonate (4.4\%) with a final $\mathrm{pH}$ of 6.8-7.2 at $37^{\circ} \mathrm{C}$ in a humidified incubator with $5 \% \mathrm{CO}_{2}$.

\section{Cytotoxicity assay}

$\mathrm{RD}$ and REF cells, cultured as described above, were seeded on micro-titration (96-well plates at a concentration of $1 \times 10^{4}$ cells/well) in quadruple, and various concentrations of ciprofloxacin (from 62.5 to $1000 \mathrm{mcg} / \mathrm{ml}$ ) were added. The cells were incubated for $24 \mathrm{~h}$ at $37^{\circ} \mathrm{C}$ in $5 \% \mathrm{CO}_{2}$ atmosphere. For the last $3 \mathrm{~h}$ of incubation, crystal violet stain $200 \mu \mathrm{l}$ in phosphatebuffered saline (PBS) was added to each well. The plates were incubated for 20 minutes at $37^{\circ} \mathrm{C}$. After incubation, excess dye removed by washing the well three times with PBS.

The optical density of each well was read by using a micro-ELISA reader at a transmitting wavelength on $492 \mathrm{~nm}$ with a spectrophotometer (ELISA multi-well Reader, Organon-teknica, Austria) ${ }^{6,7}$.

The percentage of growth inhibition was calculated according to the following equation ${ }^{8}$.

$$
\text { IR } \%=\frac{A-B}{A} \times 100
$$

$\mathrm{IR}=$ inhibition rate,

$A=$ optical density of control (zero) concentration, $\mathrm{B}=$ optical density of each drug concentration.

Furthermore, digitalized camera was utilized to take pictures concerning the possible changes in growth of each cell line exposed to ceftriaxone and compared that with cells not exposed to the drug.

Statistical analysis

Data were analyzed by 2-way analysis of variance with ANOVA. Data are presented as means $\pm \mathrm{SD}$. The level of significance $(p<0.05)$ was used for analysis of variance in all results presented in this study. 
Nada N. Al-Shawi / IJRAP 4(1), Jan-Feb 2013

Table 1: The effects of different concentration of ceftriaxone on growth of human Rhabdomyosarcoma (RD) cell line

\begin{tabular}{|c|c|c|}
\hline Concentration meg/ml & Inhibition rate (mean+SD) & \% of Growth Inhibition \\
\hline Control (0) & $0.362 \pm 0.047$ & -6.629 \\
\hline Ceftriaxone 62.5 & $\mathrm{A}: 0.386 \pm 0.0174$ & 34.806 \\
\hline Ceftriaxone 125 & $\mathrm{B}, *: 0.236+0.0453$ & 86.187 \\
\hline Ceftriaxone 250 & $\mathrm{C}, *: 0.05 \pm 0.0051$ & 68.701 \\
\hline Ceftriaxone 500 & $\mathrm{B}, *: 0.1133 \pm 0.0393$ & 86.87 \\
\hline Ceftriaxone 1000 & $\mathrm{B}, *: 0.0475 \pm 0.002$ & - \\
\hline
\end{tabular}

- Non-identical capital letters (A, B and C) are considered significant $(\mathrm{P}<0.05)$ among RD cell lines exposed to different concentrations of ceftriaxone.

- * $\mathrm{P}<0.05$ : significant difference compared to untreated cell (control).

- Negative results of the $\%$ growth inhibition indicate proliferation.

- Positive results of the $\%$ growth inhibition indicate anti-proliferation.

Table 2: The effects of different concentration of ceftriaxone on growth of rat embryo fibroblast (REF) cell line

\begin{tabular}{|c|c|c|}
\hline Concentrations (mcg/ml) & Inhibition rate (Mean \pm SD) & \% of growth inhibition \\
\hline Control (0) & $0.279 \pm 0.005$ & -29.391 \\
\hline Ceftriaxone 62.5 & $\mathrm{A}, *: 0.361 \pm 0.0195$ & 18.996 \\
\hline Ceftriaxone 125 & $\mathrm{B}, *: 0.226 \pm 0.0194$ & 62.007 \\
\hline Ceftriaxone 250 & $\mathrm{B}, *: 0.106 \pm 0.0215$ & 59.498 \\
\hline Ceftriaxone 500 & $\mathrm{B}, *: 0.113 \pm 0.0925$ & 80.645 \\
\hline Ceftriaxone 1000 & $\mathrm{C}, *: 0.054 \pm 0.0043$ & \\
\hline
\end{tabular}

- Non-identical capital letters (A, B and C) are considered significant $(\mathrm{P}<0.05)$ among REF cell lines exposed to different concentrations of ciprofloxacin.

* $\mathrm{P}<0.05$ : significant difference compared to un-treated cells (control)

-Negative results of the $\%$ growth inhibition indicates proliferation.

-Positive results of the $\%$ growth inhibition indicates anti-proliferation.

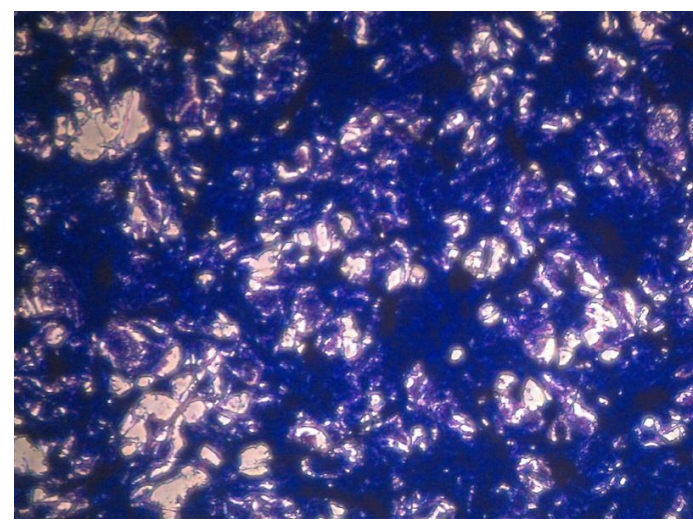

Figure 1: Cohesive cells of Rhabdomyosarcoma (RD) un-exposed to $1000 \mathrm{mcg} / \mathrm{ml}$ ceftriaxone

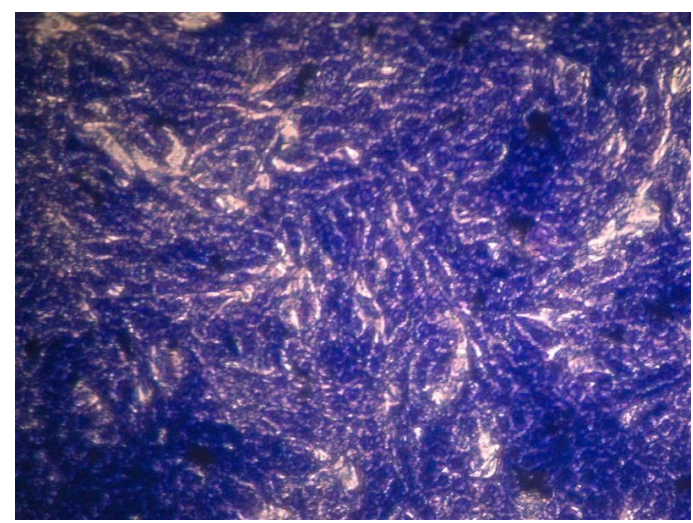

Figure 3: Cohesiveness of Rhabdomyosarcoma (RD) cells unexposed to $1000 \mathrm{mcg} / \mathrm{ml}$ ceftriaxone

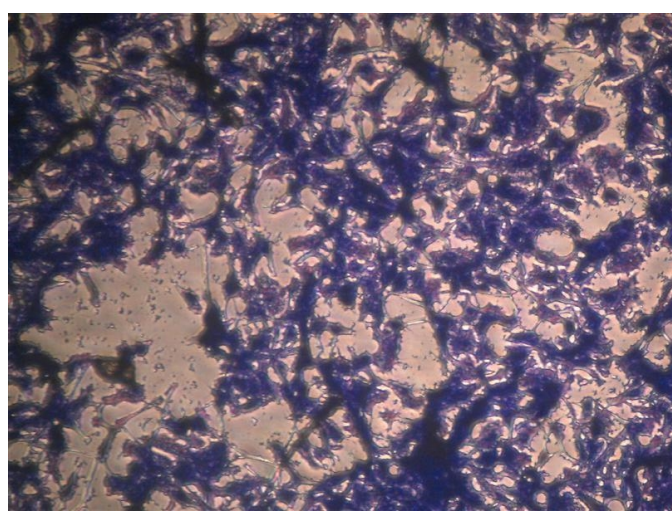

Figure 2: Manifestation of feature loss of RD cell line exposed to $1000 \mathrm{mcg} / \mathrm{ml}$ ceftriaxone for $48 \mathrm{~h}$ with marked decrease in viability cell number

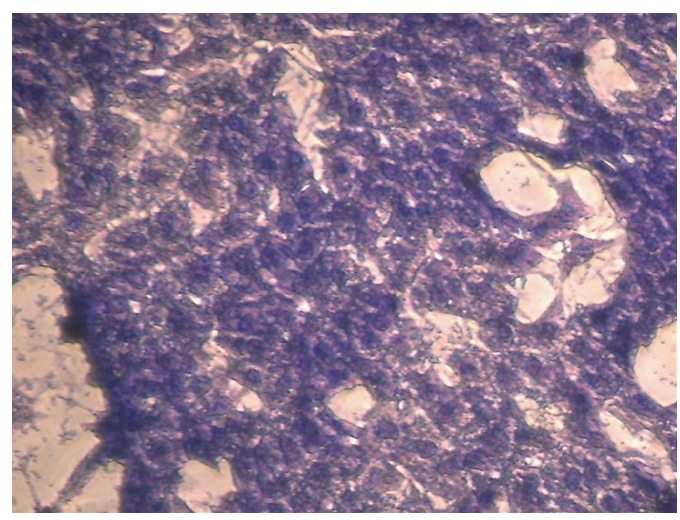

Figure 4: Manifestation of feature loss of REF cell line exposed to $1000 \mathrm{mcg} / \mathrm{ml}$ ceftriaxone for $48 \mathrm{hrs}$ with marked decrease in viability cell number 


\section{RESULTS}

Table 1 demonstrated the results of various concentrations (from 62.5 to 1000) of ceftriaxone each applied to RD cell lines for $48 \mathrm{hrs}$. There was no significant growth inhibition provoked by $62.5 \mathrm{mcg} / \mathrm{ml}$ ceftriaxone concentration compared to cells not exposed to the drug $(\mathrm{P}>0.05)$; while, there were significant growth inhibition observed at $125,250,500$ and $1000 \mathrm{mcg} / \mathrm{ml}$ drug concentration $(\mathrm{P}<0.05)$ on the RD cell line compared to cells not treated with the drug $(0 \mu \mathrm{g} / \mathrm{ml})$. The percent of growth inhibition were $34.806,86.187,68.701$ and $86.87 \%$, respectively. (Table 1)

Concerning morphological features of RD cell lines, figure 2 demonstrated that maximum concentration of ceftriaxone $(1000 \mathrm{mcg} / \mathrm{ml})$ used in this study caused feature loss of RD cell line exposed to the drug for $48 \mathrm{hrs}$ with marked decrease in viability cell number of the intended cell line in comparison with confluent monolayer and cohesiveness of RD before exposure to such concentration of the drug. (Figure 1)

The results of this study demonstrated that the intended concentrations of ceftriaxone caused similar effects which were observed concerning REF cell lines; where, there was no significant growth inhibition provoked by 62.5 $\mathrm{mcg} / \mathrm{ml}$ ceftriaxone concentration compared to cells not exposed to the drug $(\mathrm{p}>0.05)$; while, there were significant growth inhibition observed at 125, 250, 500 and $1000 \mathrm{mcg} / \mathrm{ml}$ drug concentration $(\mathrm{p}<0.05)$ on the REF cell line compared to cells not treated with the drug $(0$ $\mu \mathrm{g} / \mathrm{ml})$. The percent of growth inhibition were 18.996, $62.007,59.498$ and $80.645 \%$, respectively. (Table 2)

Concerning morphological features of REF cell lines, figure 4 demonstrated that maximum concentration of ceftriaxone $(1000 \mathrm{mcg} / \mathrm{ml})$ used in this study caused feature loss of REF cell line exposed to the drug for $48 \mathrm{~h}$ with marked decrease in viability cell number of the intended cell line in comparison with confluent monolayer and cohesiveness of RD before exposure to such concentration of the drug. (Figure 3)

\section{DISCUSSION}

Many authors have been reported that antibiotics like cefazoline, ciprofloxacin, co-trimoxazole and moxifloxacin have the ability to inhibit growth utilizing various cell lines ${ }^{4,5}$. But, there was no In vitro study demonstrating the effect of different concentrations of ceftriaxone on growth of cell lines.

The present study revealed that when human rhabdomyosarcoma (RD) or rat embryo fibroblasts (REF) cell lines was exposed to ceftriaxone, a beta lactam antibiotic for $48 \mathrm{hrs}$ produced growth inhibition relatively in concentration-dependent manner (from $125 \mathrm{mcg}$ to $1000 \mathrm{mcg} / \mathrm{ml}$ ). By comparing the result of this study with the other one which was performed on other drug, the growth inhibitory action of various concentrations of ceftriaxone on the previously-mentioned cell lines can be attributed to the sensitivity of both cell lines to the cytoxic activity of the drug 9 .

Cephalosporins are beta lactam-containing compounds, used for treatment of bacterial infection ${ }^{10}$. They have also been used in selective targeting of anticancer compounds to tumor cells utilizing antibody-directed enzyme prodrug therapy $(\mathrm{ADEPT})^{11-15}$.

In addition, there are many types of antibiotics (e.g. anthracyclines, bleomycin) that have been used to treat cancer. However, research into the possibility of utilizing beta-lactam antibiotics as potential anticancer medications has been relatively non-existent. It has been demonstrated that beta-lactams could play a role as anticancer drugs ${ }^{16}$, 17.

The results of this In vitro study may provide an additional evidence for the effect of various concentrations of ceftriaxone on growth of two cell lines, (RD and REF) used in this study, where a concentrationdependent anti-proliferative effects of ceftriaxone were observed; thus, ceftriaxone may prove useful as a potential preventive and/or therapeutic agent as an anticancer agent. Further studies are needed to completely assess the antiproliferative effect of the drug utilizing In vivo model.

\section{REFERENCES}

1. Gladwin, Mark. Clinical Microbiology Made Ridiculously Simple 4th ed. Miami, FL: Med Master, Inc. 2007. p 67.

2. Newton, Gehan, and Webber, et al. Classification of rhabdomyosarcomas and related sarcomas. Pathologic aspects and proposal for a new classification, an inter-group rhabdomyosarcoma study. Cancer. 1995; 76 (6): 1073-1085. http://dx.doi.org/ 10.1002/1097-0142(19950915)76:6<1073::AIDCNCR2820760624>3.0.CO;2-L

3. Al-Shamery, AMH. The study of Newcastle disease virus effect in the treatment of transplanted tumor in mice. MSc. Thesis, College of Veterinary Medicine, University of Baghdad, Iraq. 2003.

4. Kamat AM and Lamm DL. Antitumor activity of common antibiotics against superficial bladder cancer. Urology. 2004; 63(3): 457-60.http://dx.doi.org/10.1016/j.urology.2003.10.038PMid: 15028437

5. Fabian I, Reuveni D, Levitov A, Halperin D, Priel E and Shalit I. Moxifloxacin enhances antiproliferative and apoptotic effects of etoposide but inhibits its proinflammatory effects in THP-1 and Jurkat cells. Br J. Cancer. 2006; 95: 1038-1046. http://dx.doi.org/ 10.1038/sj.bjc.6603355 PMid:17047652 PMCid:2360706

6. Mahony DE, Gilliant E, Dawson $\mathrm{S}$ et al. Vero cell assay for rapid detection of clostridium perfringens enterotoxin. J. Applied Environ Microbiol. 1989; 55(9):2141-2143.

7. Freshney RI. Culture of animal cells: A manual of basic technique (3rd ed), Wiley-Liss Company, NewYork. 1994; p 201-292.

8. Chiang LC, Chang MY and Lin CC. In vitro cytotoxic, antiviral and immunomodulatory effect. J American of Chinese Medicine 2003; 31:225-234.http://dx.doi.org/10.1142/S0192415X03000874PMid: 12856861

9. Lafta AJ. Antiproliferative activity of spironolactone: in vitro and in vivo study. MSc. Thesis, College of Pharmacy, University of Baghdad, Iraq. 2010.

10. Burton HS and EP Abraham. Isolation of antibiotics from a species of Cephalosporium: cephalosporins P1, P2, P3, P4 and P5. Biochem J. 1951; 50:168-170. PMid:14904388 PMCid:1197626

11. Bagshawe KD. Antibody directed enzymes revive anticancer prodrug concepts. Br J Cancer. 1978; 56: 531-532. http://dx.doi.org/ $10.1038 / \mathrm{bjc} .1987 .237$

12. Bagshawe KD, CJ Springer, F Searle, P Antoniw, SK Sharma, RG Melton and RF Sherwood. A cytotoxic agent can be generated selectively at cancer sites. $\mathrm{Br} \mathrm{J}$ Cancer. 1988; 58: 700-703 http://dx.doi.org/10.1038/bjc.1988.293PMid:3265633,PMCid:22468 64

13. Koppel GA. Recent advances with monoclonal antibody drug targeting for the treatment of human cancer. Bioconjugate Chem. 1990;1:13-23.http://dx.doi.org/10.1021/bc00001a002PMid:2095201

14. Jungheim LN and TA Shepherd. Design of antitumor prodrugs: Substrates for antibody targeted enzymes. Chem Rev. 1994; 94: 1553-1566. http://dx.doi.org/10.1021/cr00030a004

15. Senter PD and CJ Springer. Selective activation of anti-cancer prodrugs by monoclonal antibody-enzyme conjugates. Adv Drug Deliv 
Nada N. Al-Shawi / IJRAP 4(1), Jan-Feb 2013

Rev.2001;53:247-264.http://dx.doi.org/10.1016/S0169409X(01) 00206-X

16. Smith DM, A Kazi, L Smith, TE Long, B Heldreth, E Turos and QP Dou. A novel beta-lactam antibiotic activates tumor cell apoptotic program by inducing DNA damage. Mol Pharmacol. 2002; 61:1348-1358http://dx.doi.org/10.1124/mol.61.6.1348PMid: 12021396

17. Kazi A, R Hill, TE Long, DJ Kuhn, E Turos and QP Dou. Novel Nthiolated beta-lactam antibiotics selectively induce apoptosis in human tumor and transformed, but not normal or non-transformed cells. Biochem Pharmacol. 2004; 67: 365-374. http://dx.doi.org/ 10.1016/j.bcp.2003.09.017 PMid:14698048

Cite this article as:

Nada N. Al-Shawi. In vitro effects of Ceftriaxone on growth of Human Rhabdomyosarcoma (RD) and on Rat Embryo Fibroblasts (REF) cell

lines. Int. J. Res. Ayur. Pharm. 2013; 4(1):42-45

Source of support: Nil, Conflict of interest: None Declared 